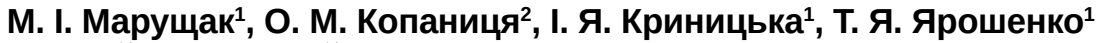

ТЕРНОПІЛЬСЬКИЙ ДЕРЖАВНИЙ МЕДИЧНИЙ УНІВЕРСИТЕТ ІМЕНІ І. Я. ГОРБАЧЕВСЬКОГО РІВНЕНСЬКИЙ ДЕРЖАВНИЙ БАЗОВИЙ МЕДИЧНИЙ КОЛЕДЖ

\title{
ПЕРОКСИДНЕ ОКИСНЕННЯ БІЛКІВ СТІНКИ ТОНКОЇ КИШКИ, МІОКАРДА ТА ПЕЧІНКИ ЩУРІВ ПРИ ЕКСПЕРИМЕНТАЛЬНОМУ ЗАСТОСУВАННI КАРАГІНАНУ
}

Вступ. В останні десятиріччя карагінани стали одними з найпопулярніших гідроколоїдів у харчовій промисловості. Окрім позитивних властивостей гідроколоїдів, дослідники встановили взаємозв'язок між захворюваністю на виразковий коліт і рівнем споживання карагінану. 3 огляду на це, його розглядають як потенційний етіологічний чинник патології шлунково-кишкового тракту людини.

Мета дослідження - встановити рівень окиснювальної модифрікації білків стінки тонкої кишки, тканин серця і печінки щурів при застосуванні 1 \% розчину к-карагінану.

Методи дослідження. Дослідження проведено на 24 білих нелінійних щурах-самцях. Тваринам дослідної групи забезпечували вільний доступ до 1,0 \% розчину карагінану в питній воді протягом 1 місяця. У відібраних зразках тонкої кишки, серця та печінки оцінювали пероксидне окиснення білків за кількістю продуктів їх окиснювальних модифрікацій за допомогою спектрофротометрії при довжині хвилі 370 і 430 нм.

Результати й обговорення. Встановлено достовірне зростання кетонодинітрофренілгідразонів у стінці тонкої кишки (на 57,0 \%) і печінці (на 23,0 \%) та, відповідно, альдегідодинітрофренілгідразонів на 47,7 і 19,1 \% проти контрольних значень (p<0,01). При цьому пероксидного окиснення більшою мірою зазнавали білки нейтрального характеру. Слід зазначити, що пероксидне окиснення білків у міокарді при застосуванні карагінану, зареєстроване при довжині хвилі 370 нм, перевищувало на 14,3\% дані контролю $(p<0,05)$.

Висновок. Пероральне застосування 1 \% розчину карагінану призводить до статистично значимої активації пероксидного окиснення білків у стінці тонкої кишки і печінці щурів, тоді як у міокарді зареєстровано тільки зростання нейтральних кетонодинітрофренілгідразонів $(p<0,05)$.

КЛЮЧОВІ СЛОВА: окиснювальна модифрікація білків; карагінан; експеримент.

ВСТУП. В останні десятиріччя карагінани стали одними з найпопулярніших гідроколоїдів у харчовій промисловості [1-3]. Основним їх призначенням $€$ утворення гелів, тому карагінани широко використовують як емульгатори, стабілізатори, загусники. Враховуючи те, що карагінани належать до розчинних харчових волокон, вони беруть участь у регулюванні гомеостазу, мають імуностимулювальну й антикоагулянтну властивості, що робить цікавим їх застосування в харчових продуктах фрункціонального призначення $[4,5]$. Згідно з даними Л. А. Текутьєва, використання карагінанів приводить до значної економії сировини і здешевлення готової продукції. Автор зазначає, що 1 кг високоякісно-

(c) М. І. Марущак, О. М. Копаниця, І. Я. Криницька, Т. Я. Ярошенко, 2017. го карагінану дозволяє замінити від 70 до 100 кг м'яса [6]. Застосовують карагінан також як стабілізатор, емульгатор, загусник і гелеутворювач під час виготовлення кондитерських виробів, молочних продуктів, морозива, напівфрабрикатів сніданків, дитячого харчування, м'яких сирів, м'ясних консерв, приправ, безалкогольних напоїв, хлібобулочних виробів, соусів, майонезів [7]. Окрім позитивних властивостей гідроколоїдів, дослідники встановили взаємозв'язок між захворюваністю на виразковий коліт і рівнем споживання карагінану. 3 огляду на це, його розглядають як потенційний етіологічний чинник патології шлунково-кишкового тракту людини.

Можна виділити різні типи карагінанів, що відрізняються вмістом 3,6-ангідрогалактози, місцем розташування і кількістю сульфратних 
груп. Відомо понад 18 типів і структур карагінанів. За хімічною будовою к-карагінан, який найчастіше використовують у харчових продуктах, являє собою гетерополісахарид червоних морських водоростей Rhodophyceae, що містить один складний сульфратний ефрір, розміщений у циклі галактопіранози в положенні 4 [8-10].

В основі усіх сучасних концепцій розвитку різних захворювань лежить порушення структури клітинної мембрани, одним із чинників пошкодження якої є пероксидне окиснення. Нині велика зацікавленість дослідників спрямована на вивчення механізмів взаємодії активних фоорм оксигену з білками, оскільки відомо, що за умов оксидативного стресу розвиваються процеси неконтрольованої модифрікації білків, які зумовлюють їх фррагментацію, денатурацію, а також утворення первинних амінокислотних радикалів, що далі вступають у вторинну взаємодію із сусідніми амінокислотними залишками, створюючи надзвичайно складну картину пошкоджувальної дії кисневих радикалів на білкові макромолекули [11]. Тому дослідники схиляються до думки, що кисневозалежне окиснення білків $\epsilon$ раннім індикатором пошкодження органів і тканин [12].

Мета дослідження - встановити рівень окиснювальної модифрікації білків (ОМБ) стінки тонкої кишки, тканин серця і печінки щурів при застосуванні $1 \%$ розчину к-карагінану.

МЕТОДИ ДОСЛІДЖЕННЯ. Дослідження проведено на 24 білих нелінійних щурах-самцях, яких утримували на стандартному раціоні віварію Тернопільського державного медичного університету імені І. Я. Горбачевського. Під час роботи дотримувалися принципів Європейської конвенції про захист хребетних тварин, що використовуються для дослідних та інших наукових цілей (Страсбург, 1986). Піддослідних щурів поділили на 2 групи: 1-ша - контроль (інтактні тварини); 2-га - тварини, які вживали карагінан. Тваринам 2-ї групи було забезпечено вільний доступ до 1,0 \% розчину карагінану в питній воді протягом 1 місяця [13, 14].

Відбирали зразки стінки тонкої кишки, серця і печінки, відмивали у фізіологічному розчині. Наважки тканин по 1 г гомогенізували на льодяній бані на гомогенізаторі в бусрерному розчині [15]. Кількість протеїну в кожному зразку визначали за методом О. H. Lowry [16]. Рівень пероксидного окиснення білків встановлювали у всіх досліджуваних тканинах за кількістю продуктів їх окиснювальних модифікацій за допомогою спектросотометрії при довжині хвилі 370 і 430 нм. Методика ґрунтується на реакції взаємодії окиснених амінокислотних залишків білків із 2,4-динітрофренілгідразином 3 утворенням похідних 2,4-динітрофенілгідразону, оптичну щільність яких визначали спектрофротометрично. Відомо, що в результаті окиснення білків, залежно від переважання в їх молекулах амінокислот нейтрального (валін, лейцин, ізолейцин та ін.) або основного (лізин, аргінін тощо) характеру, утворюються альдегідо- чи кетонопохідні нейтрального або основного характеру, які мають різні діапазони спектра поглинання. При довжині хвилі 370 нм визначають кетонодинітрофенілгідразони нейтрального характеру, при довжині хвилі 430 нм реєструють, відповідно, альдегідодинітрофенілгідразони основного характеру [17].

Отримані дані піддавали статистичній обробці $[18,19]$. Для перевірки на відповідність вибірок даних нормальному закону розподілу було застосовано розрахунок критерію ШапіроУїлка. У зв'язку з відсутністю відповідності даних нормальному розподілу на рівні значимості p $<0,05$, рівень статистичної значущості відмінностей вибірок оцінювали за допомогою непараметричного критерію Манна-Уїтні. Відмінності вважали статистично значущими при досягнутому рівні $p<0,05$.

РЕЗУЛЬТАТИ Й ОБГОВОРЕННЯ. ВСТаНОВлено достовірне зростання кетонодинітрофенілгідразонів у стінці тонкої кишки (на 57,0 \%) і печінці (на 23,0 \%) та, відповідно, альдегідодинітрофенілгідразонів на 47,7 і 19,1 \% проти контрольних значень $(p<0,01)$ (табл.). При цьому пероксидного окиснення більшою мірою зазнавали білки нейтрального характеру. Слід зазначити, що пероксидне окиснення білків у міокарді при застосуванні карагінану, зареєстроване при довжині хвилі 370 нм, перевищувало на $14,3 \%$ дані контролю $(p<0,05)$.

Отже, у тварин, які мали вільний доступ до 1,0 \% розчину карагінану в питній воді протягом 1 місяця, спонтанне окиснювання білків у тканині тонкої кишки і печінки вказує не лише на ініціацію процесів вільнорадикального окиснення (підвищення альдегідодинітрофенілгідразонів), але й на виснаження резервно-адаптаційних можливостей організму (зростання кетонодинітрофенілгідразонів) [20, 21].

Виявлене посилення ступеня окиснювальної деструкції білкових молекул у стінці тонкої кишки і печінці вказує на вихід з-під контролю захисно-пристосувальних реакцій клітини, свідчить про порушення механізмів регуляції ферментних систем, які забезпечують клітинний гомеостаз, оскільки відомо, що за умов оксидативного стресу активні фоорми оксигену впливають передусім на білки плазматичних мембран, і призводить до сильної гістодеструкції [22]. 
Таблиця - Показники окиснювальної модифрікації білків (опт. од./г протеїну) стінки тонкої кишки, міокарда та печінки щурів за умови вживання 1 \% розчину карагінану в питній воді протягом

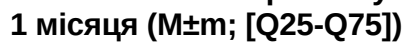

\begin{tabular}{|c|c|c|}
\hline Показник & Контрольна група $(\mathrm{n}=12)$ & Дослідна група (n=12) \\
\hline \multicolumn{3}{|c|}{ Тканини стінки тонкої кишки } \\
\hline ОМБ, $\lambda=370$ нм & $\begin{array}{c}0,35 \pm 0,01 \\
{[0,34 ; 0,37]}\end{array}$ & $\begin{array}{l}0,55 \pm 0,01^{*} \\
{[0,53 ; 0,57]}\end{array}$ \\
\hline ОМБ, $\lambda=430$ нм & $\begin{array}{c}0,27 \pm 0,01 \\
{[0,26 ; 0,29]}\end{array}$ & $\begin{array}{l}0,41 \pm 0,02^{*} \\
0,38 ; 0,42]\end{array}$ \\
\hline \multicolumn{3}{|c|}{ Тканини міокарда } \\
\hline ОМБ, $\lambda=370$ нм & $\begin{array}{c}1,65 \pm 0,04 \\
{[1,56 ; 1,75]}\end{array}$ & $\begin{array}{l}1,85 \pm 0,03^{*} \\
{[1,78 ; 1,94]}\end{array}$ \\
\hline OMБ, $\lambda=430 \mathrm{HM}$ & $\begin{array}{c}0,75 \pm 0,04 \\
{[0,65 ; 0,84]}\end{array}$ & $\begin{array}{c}0,82 \pm 0,03 \\
{[0,77 ; 0,90]}\end{array}$ \\
\hline \multicolumn{3}{|c|}{ Тканини печінки } \\
\hline OMБ, $\lambda=370 \mathrm{HM}$ & $\begin{array}{c}0,38 \pm 0,01 \\
{[0,36 ; 0,40]}\end{array}$ & $\begin{array}{l}0,47 \pm 0,01^{*} \\
{[0,45 ; 0,50]}\end{array}$ \\
\hline ОМБ, $\lambda=430$ нм & $\begin{array}{c}0,30 \pm 0,01 \\
{[0,28 ; 0,31]}\end{array}$ & $\begin{array}{l}0,35 \pm 0,01^{*} \\
{[0,34 ; 0,37]}\end{array}$ \\
\hline
\end{tabular}

Примітка. * - відмінність достовірна стосовно контролю $(p<0,05)$.

ВИСнОВОК. Пероральне застосування $1 \%$ розчину карагінану призводить до статистично значимої активації пероксидного окиснення білків у стінці тонкої кишки і печінці щурів, тоді як у міокарді зареєстровано тільки зростання нейтральних кетонодинітрофенілгідразонів $(p<0,05)$.
Перспективи подальших досліджень. Планується встановити кореляційні зв'язки між досліджуваними показниками в тканинах організму щура при застосуванні 1 \% розчину карагінану.

\section{СПИСОК ЛІТЕРАТУРИ}

1. Филлипс Г. О. Справочник по гидроколлоидам / Г. О. Филлипс, П. А. Вильямс. - СПб. : ГИОРД, 2006. $536 \mathrm{c}$.

2. Пат. на корисну модель 53127 Україна, МПК A23L 1/06. Желейний мармелад / Дорохович A. М., Соловйова О. Л., Бондарук Ю. К. - № u201003479 ; заявл. 25.03.10 ; опубл. 27.09.10, Бюл. № 18.

3. Пат. на корисну модель 92401 Україна, МПК A23L 1/325, A23B 4/00. Спосіб приготування рибних консервів в желе / Богомолова В. В. - № a 200900303 ; заявл. 16.01.09 ; опубл. 25.10.10, Бюл. № 20.

4. Пасальський В. К. Хімія харчових продуктів / В. К. Пасальський. - К. : Київ. держ. торг.-екон. ун-т, 2009. - 196 c.

5. Биотехнология мяса и мясопродуктов : курс лекций / И. А. Рогов, А. И. Жаринов, Л. А. Текутьева, Т. А. Шепель. - М. : ДеЛи принт, 2009. - 296 с.

6. Текутьева Л. А. Высокоочищенные каррагинаны - скрытый резерв экономической эфффективности / Л. А. Текутьева // Мясной ряд. - 2003. - № 3. C. 36-37.

7. Кучерук 3. І. Використання полісахаридів рослинного і мікробного походження в технології безбілкового хліба : монографрія / 3. І. Кучерук, О. С. Цуканова. - Х. : ХДУХТ, 2014. - 131 с.
8. Сабадош Г. О. Технологія десертів молочних 3 використанням карагінанів : дис. ... канд. техн. наук : 05.18.16 / Сабадош Ганна Олександрівна. - Харків, 2010. - 276 c.

9. Светлаков Д. Б. Разработка композиций на основе каппа-каррагинана для регулирования реологических свойств эмульгированных мясопродуктов : дисс. ... канд. техн. наук : 05.18.07 / Светлаков Денис Борисович. - М., 2004. - 117 с.

10. Marine Colloids. Каррагинан. Технологическая инорормация [Электронный ресурс] / Marine ColloidsРежим доступа : http://biokhim.com/data2/fmc/FMC\%20 biopolymer.pdf.

11. Денисенко О. І. Окисна модифрікація білків як чинник патогенезу алергодерматозів / О.І.Денисенко // Укр. журн. дерматології, венерології, косметолоriï. - 2004. - № 1. - С. 23-26.

12. Окислительная модисикация белков плазмы крови у больных в критических состояниях / Г. Я. Рябов, Ю. М. Азизов, С. И. Дорохов [и др.] // Анестезиол. и реаниматол. - 2000. - № 2. - С. 72-75.

13. Moyana T. N. Carrageenan-induced intestinal injury in the rat - a model for inflammatory bowel disease I T. N. Moyana, J. M. Lalonde // Ann. Clin. Lab. Sci. 1990. - 20 (6). - P. 420-426. 
14. Пат. 97322 Україна, МПК G09B 23/28. Спосіб моделювання хронічного гастроентероколіту / Губіна-Вакулик Г. І., Колоусова Н. Г., Іваненко Т. О., Горбач Т. В., Коробчанський В. О.; власник Харк. нац. мед. ун-т. - № а201014510 ; заявл. 06.12.10 ; опубл. 25.01.12, Бюл. № 2.

15. Nesterova L. A. Characterization of specific binding blocker $[+\mathrm{H}]$ - quinuclidinylbenzilate $\mathrm{M}$-cholinergic receptors in rat brain cortex membranes / L. A. Nesterova, E. A. Smurova, B.N. Manukhin // Reports of the Academy of Sciences. - 1995. - № 343 (2). - P. 268-271.

16. Lowry O. H. Protein measurement with the Folin phenol reagent / O. H. Lowry // Journal of Biological Chemistry. - 1951. - № 193 (1). - P. 404-415.

17. Семенюк Г. Д. Стан інтенсивності окиснювальної модифікації білків та активності антиоксидантних фрерментів у ротовій рідині хворих на генералізований пародонтит / Г. Д. Семенюк, Г. М. Мельничук, Г. М. Ерстенюк / Арх. клініч. медицини. - 2013. - № 2 (19). C. $69-71$.

\section{REFERENCES}

1. Fillips, G.O., \& Vilyams, P.A. (2006). Spravochnik po gidrokolloidam [Handbook of hydrocolloids]. Saint Petersburg: GIORD [in Russian].

2. Dorokhovych, A.M., Soloviova, O.L., Bondaruk, Yu.K. (2010). Zheleinyi marmelad [Jelly Marmalade]. Patent Ukraina, № u201003479 [in Ukrainian].

3. Bohomolova, V.V. (2009). Sposib pryhotuvannia rybnykh konserviv $v$ zhele [Method of preparation of canned fish in jelly]. Patent Ukraina, № a 200900303 [in Ukrainian].

4. Pasalskyi, V.K. (2009). Khimiia kharchovykh produktiv [Chemistry of food products]. Kyiv: KDTEU [in Ukrainian].

5. Rogov, I.A., Zharinov, A.I., Tekuteva, L.A., \& Shepel, T.A. (2009). Biotehnologiya myasa i myasoproduktov: kurs lektsiy [Biotechnology of meat and meat products: a course of lectures]. Moscow: DeLi print [in Russian].

6. Tekuteva, L.A. (2003). Vysokoochischennyye karraginany - skrytyy rezerv ekonomicheskoy effektivnosti [Highly purified carrageenans - a hidden reserve of economic efficiency]. Myasnoy ryad-Meat Row, 3, 36-37 [in Russian].

7. Kucheruk, Z.I., \& Tsukanova, O.S. (2014). Vykorystannia polisakharydiv roslynnoho i mikrobnoho pokhodzhennia $v$ tekhnolohii bezbilkovoho khliba: monohrafiia [The use of polysaccharides of plant and microbial origin in the technology of non-protein bread: a monograph]. Kharkiv: KhDUKhT [in Ukrainian].

8. Sabadosh, H.O. (2010). Tekhnolohiia desertiv molochnykh z vykorystanniam karahinaniv [Technology of dairy desserts using carrageenans]. Extended abstract of Candidate's thesis. Kharkiv [in Ukrainian].

9. Svetlakov, D.B. (2004). Razrabotka kompozitsiy na osnove kappa-karraginana dlya regulirovaniya reologicheskikh svoystv emulgirovannykh myasoproduktov
18. Гланц С. Медико-биологическая статистика / С. Гланц ; пер. с англ. - М. : Практика, 1999. - 459 с.

19. Реброва О. Ю. Статистический анализ медицинских данных. Применение пакета прикладных программ STATISTICA / О. Ю. Реброва. - М. : МедиаCopepa, 2002. - 312 c.

20. Мялюк О. П. Стан вільнорадикального окиснення у тканинах печінки експериментальних щурів при аліментарному ожирінні / О. П. Мялюк // Вісн. проблем біології і медицини. - 2015. - Вип. 4 (1). C. 120-123.

21. Маракушин Д. І. Вплив оксиетильованих нонілсенолів та їх похідних на процеси ліпопероксидації та окисної модисрікації білків в організмі щурів / Д. І. Маракушин // Здобутки клініч. і експерим. медицини. - 2015. - № 1. - С. 94-97.

22. Зинь А. Окисна модифрікація білків у зародках в'юна MISGURNUS FOSSILIS L. упродовж ембріогенезу за дії гіпохлориту натрію / А. Зинь, Н. Головчак, Д. Санагурський // Вісн. Львів. ун-ту. Серія біологічна. 2013. - Вип. 61. - С. 11-19.

[Development of compositions based on kappa-carrageenan for regulating the rheological properties of emulsified meat products]. Extended Abstract of Candidate's thesis. Moscow [in Russian].

10. Colloids, M. (2007). Karraginan. Tehnologicheskaya informatsiya [Carrageenan. Technological information]. Philadelphia: Retrieved from: http//biokhim.com/ data2/fmc/FMC\%20biopolymer.pdf

11. Denysenko, O.I. (2004). Okysna modyfikatsiia bilkiv yak chynnyk patohenezu alerhodermatoziv [Oxidative modification of proteins as a factor in the pathogenesis of allergic dermatitis]. Ukrainskyi zhurnal dermatolohii, venerolohii, kosmetolohii - Ukrainian Journal of Dermatology, Venereology, Cosmetology, 1, 23-26 [in Ukrainian].

12. Ryabov, G.Ya., Azimov, Yu.M., \& Dorohov, S.I. (2000). Okislitelnaya modifikatsiya belkov plazmy krovi u bolnykh v kriticheskikh sostoyaniyakh [Oxidative modification of plasma proteins in patients in critical conditions]. Anesteziologiya i reanimatologiya - Anesthesiology and Reanimatology, 2, 72-75 [in Ukrainian].

13. Moyana, T.N., \& Lalonde, J.M. (1990). Carrageenan-induced intestinal injury in the rat - a model for inflammatory bowel disease. Ann. Clin. Lab. Sci., 20, 6, 420-426.

14. Hubina-Vakulyk, H.I., Kolousova, N.H., Ivanenko, T.O., Horbach, T.V., \& Korobchanskyi, V.O. (2012). Sposib modeliuvannia khronichnoho hastroenterokolitu [Method of modeling chronic gastroenterocolitis]. Patent Ukraina, № a201014510 [in Ukrainian].

15. Nesterova, L.A., Smurova, E.A., \& Manukhin, B.N. (1995). Characterization of specific binding blocker [+ $\mathrm{H}]$-quinuclidinylbenzilate Mcholinergic receptors in rat brain cortex membranes. Reports of the Academy of Sciences, 343 (2), 268-271. 
16. Lowry, O.H. (1951). Protein measurement with the Folin phenol reagent. Journal of Biological Chemistry, 193 (1), 404-415.

17. Cemeniuk, H.D., Melnychuk, H.M., \& Ersteniuk, H.M. (2013). Stan intensyvnosti okysniuvalnoi modyfikatsii bilkiv ta aktyvnosti antyoksydantnykh fermentiv u rotovii ridyni khvorykh na heneralizovanyi parodontyt [State of intensity of oxidative modification of proteins and activity of antioxidant enzymes in the oral liquid of patients with generalized periodontitis]. Arkhiv klinichnoi medytsyny - Archive of Clinical Medicine, 69-71 [in Ukrainian].

18. Glants, S. (1999). Mediko-biologicheskaya statistika [Medical and Biological Statistics]. Moscow: Praktika [in Russian].

19. Rebrova, O.Yu. (2002). Statisticheskiy analiz meditsinskikh dannykh. Primenenie paketa prikladnykh programm STATISTICA [Statistical analysis of medical data. Application of software package STATISTICA]. Moscow: MediaSfera [in Russian].

20. Mialiuk, O.P. (2015). Stan vilnoradykalnoho okysnennia u tkanynakh pechinky eksperymentalnykh shchuriv pry alimentarnomu ozhyrinni [Condition of free radical oxidation in liver tissues of experimental rats under alimentary obesity]. Visnyk problem biolohii i medytsyny Bulletin of Biology and Medicine, 4 (1), 120-123 [in Ukrainian]

21. Marakushyn, D.I. (2015). Vplyv oksyetylovanykh nonilfenoliv ta yikh pokhidnykh na protsesy lipoperoksydatsii ta okysnoi modyfikatsii bilkiv v orhanizmi shchuriv [The influence of oxyethylvanofenylphenols and their derivatives on lipoperoxidation and oxidative modification of proteins in the rat body]. Zdobutky klinichnoi $i$ eksperymentalnoi medytsyny-Achievements of Clinical and Experimental Medicine, 1, 94-97 [in Ukrainian].

22. Zyn, A., Holovchak, D., \& Sanahurskyi, D. (2013). Okysna modyfikatsiia bilkiv u zarodkakh viuna MISGURNUS FOSSILIS L. uprodovzh embriohenezu za dii hipokhlorytu natriiu [Oxidative modification of proteins in the embryos of MISGURNUS FOSSILIS L. During the embryogenesis of the action of sodium hypochlorite]. Visnyk Lvivskoho universytetu. Seriia biolohichna Visnyk of Lviv University. Biological Series, 61, 11-19 [in Ukrainian].

М. И. Марущак ${ }^{1}$, О. М. Копаница², И. Я. Криницкая ${ }^{1}$, Т. Я. Ярошенко ${ }^{1}$ ТЕРНОПОЛЬСКИЙ ГОСУДАРСТВЕННЫЙ МЕДИЦИНСКИЙ УНИВЕРСИТЕТ ИМЕНИ И. Я. ГОРБАЧЕВСКОГО РОВНЕНСКИЙ ГОСУДАРСТВЕННЫЙ БАЗОВЫЙ МЕДИЦИНСКИЙ КОЛЛЕДЖ

\section{ПЕРЕКИСНОЕ ОКИСЛЕНИЕ БЕЛКОВ СТЕНКИ ТОНКОЙ КИШКИ, МИОКАРДА И ПЕЧЕНИ КРЫС ПРИ ЭКСПЕРИМЕНТАЛЬНОМ ПРИМЕНЕНИИ КАРРАГИНАНА}

\section{Резюме}

Вступление. В последние десятилетия каррагинаны стали одними из самых популярных гидроколоидов в пищевой промышленности. Кроме положительных свойств гидроколоидов, исследователи установили взаимосвязь между заболеваемостью язвенным колитом и уровнем потребления каррагинана. С учетом этого его рассматривют как потенциальный этиологический фрактор патологии желудочно-кишечного тракта человека.

Цель исследования - установить уровень окислительной модификации белков стенки тонкой кишки, тканей сердца и печени крыс при применении 1 \% раствора к-каррагинана.

Методы исследования. Исследование проведено на 24 белых нелинейных крысах-самцах. Животным опытной группы обеспечивали свободный доступ к 1,0 \% раствору каррагинана в питьевой воде в течение 1 месяца. В отобранных образцах тонкой кишки, сердца и печени оценивали перекисное окисление белков по количеству продуктов их окислительных модификаций с помощью спектрофотометрии при длине волны 370 и 430 нм.

Результаты и обсуждение. Установлено достоверное возрастание кетонодинитрофренилгидразонов в стенке тонкой кишки (на 57,0 \%) и печени (на 23,0 \%) и, соответственно, альдегидодинитрофенилгидразонов на 47,7 и 19,1 \% против контрольных значений (p<0,01). При этом перекисное окисление в большей степени испытывали белки нейтрального характера. Следует отметить, что перекисное окисление белков в миокарде при применении каррагинана, зарегистрированное при длине волны 370 нм, превышало на 14,3 \% данные контроля $(p<0,05)$.

Вывод. Пероральное применение 1 \% раствора каррагинана ведет к статистически значимой активации перекисного окисления белков в стенке тонкой кишки и печени крыс, тогда как в миокарде зарегистрировано только рост нейтральных кетонодинитрофренилгидразонов $(p<0,05)$.

КЛЮЧЕВЫЕ СЛОВА: окислительная модификация белков; каррагинан; эксперимент. 


\section{PEROXIDE OXIDATION OF PROTEINS IN THE SMALL INTESTINE WALL, HEART AND LIVER IN EXPERIMENTAL INTAKE OF CARRAGEENAN}

\section{Summary}

Introduction. In the last decades, the carrageenans have become one of the most popular hydrocolloids in the food industry. In addition to the positive properties of hydrocolloids, researchers have established the relationship between the incidence of ulcerative colitis and the level of carrageenan consumption, which makes it considered as a potential etiological factor in the pathology of the gastrointestinal tract.

The aim of the study - to determine the level of oxidative modification of proteins of the wall of the small intestine, tissues of the heart and liver of rats using $1 \% k$-carrageenan solution.

Materials and Methods. The study was carried out on 24 white non-linear male rats. The animals of the experimental group were provided with free access to a $1.0 \%$ of carrageenan solution for 1 month. In the selected samples of the small intestine, heart and liver was evaluated the peroxidic oxidation of proteins according to the level of their oxidation modifications products using spectrophotometry at wavelengths of 370 and $430 \mathrm{~nm}$.

Research Results. A significant increasing of ketone dinitrophenylhydrazones levels in the small intestine wall (by $57.0 \%$ ) and in the liver (by $23.0 \%$ ) and, respectively, the aldehyde dinitrophenylhydrazones levels by $47.7 \%$ and $19.1 \%$, compared with the control values $(p<0.01)$. In this case, the peroxide oxidation, to a greater extent, was subjected to neutral proteins. It should be noted that the peroxidic oxidation of proteins in the myocardium of the rats with carrageenan consumption, recorded at a wavelength of $370 \mathrm{~nm}$, exceeded the control data by $14.3 \%$ $(p<0.05)$.

Conclusion. Oral administration of a $1 \%$ carrageenan solution in experimental animals leads to statistically significant activation statistically significant activation of peroxidation of proteins in the wall of the small intestine and the liver, whereas only the growth of neutral ketone dinitrophenylhydrazones is registered in the myocardium $(p<0.05)$.

KEY WORDS: oxidation modification of proteins; carrageenan; experiment.

Адреса для листування: М. І. Марущак, Тернопільський державний медичний університет імені І. Я. Горбачевського, майдан Волі, 1, Тернопіль, 46001, Україна, e-mail: marushchak@tdmu.edu.ua. 